\title{
Correction to: Treatment response and several patient-reported outcomes are early determinants of future self-efficacy in rheumatoid arthritis
}

\author{
Michaël Doumen ${ }^{1,2^{*}}$, Diederik De Cock' ${ }^{1}$ Sofia Pazmino ${ }^{1}$, Delphine Bertrand ${ }^{1}$, Johan Joly²,
}

René Westhovens ${ }^{1,2}$ and Patrick Verschueren ${ }^{1,2}$

Correction to: Arthritis Res Ther 23, 269 (2021)

https://doi.org/10.1186/s13075-021-02651-3

Following publication of the original article [1], the authors reported an error in the presentation of author names, with first names and surnames being reversed.

The original article [1] has been updated. No changes were made to the article's content.

\section{Author details}

'Department of Development and Regeneration, KU Leuven, Skeletal Biology and Engineering Research Centre, ON IV Herestraat 49 - bus 805, 3000 Leuven, Belgium. ${ }^{2}$ Rheumatology, University Hospitals Leuven, Leuven, Belgium.
Published online: 15 November 2021

\section{Reference}

1. Doumen M, De Cock D, Pazmino S, et al. Treatment response and several patient-reported outcomes are early determinants of future self-efficacy in rheumatoid arthritis. Arthritis Res Ther. 2021;23:269. https://doi.org/10. 1186/s13075-021-02651-3.

The original article can be found online at https://doi.org/10.1186/s13075021-02651-3.

*Correspondence: michael.doumen@kuleuven.be

${ }^{2}$ Rheumatology, University Hospitals Leuven, Leuven, Belgium

Full list of author information is available at the end of the article

(c) The Author(s) 2021. Open Access This article is licensed under a Creative Commons Attribution 4.0 International License, which permits use, sharing, adaptation, distribution and reproduction in any medium or format, as long as you give appropriate credit to the original author(s) and the source, provide a link to the Creative Commons licence, and indicate if changes were made. The images or other third party material in this article are included in the article's Creative Commons licence, unless indicated otherwise in a credit line to the material. If material is not included in the article's Creative Commons licence and your intended use is not permitted by statutory regulation or exceeds the permitted use, you will need to obtain permission directly from the copyright holder. To view a copy of this licence, visit http://creativecommons.org/licenses/by/4.0/. The Creative Commons Public Domain Dedication waiver (http://creativeco mmons.org/publicdomain/zero/1.0/) applies to the data made available in this article, unless otherwise stated in a credit line to the data. 